\title{
The Effect Of Adversity Quotient On Entrepreneurial Motivation
}

\author{
Reni Respita \\ Pendidikan Ekonomi, Universitas Ekasakti, Indonesia \\ renirespita35@gmail.com
}

\begin{tabular}{|c|c|}
\hline ARTICLE INFO & ABSTRACT \\
\hline $\begin{array}{l}\text { Article History: } \\
\text { Received } \quad: 25-04-2021 \\
\text { Revised } \quad: 06-05-2021 \\
\text { Accepted } \quad: 07-05-2021 \\
\text { Online } \quad: 07-05-2021 \\
\text { Keywords: } \\
\text { Entrepreneurial; } \\
\text { Motivation; } \\
\text { Adversity } \\
\text { Quotient }\end{array}$ & $\begin{array}{l}\text { Abstract : This research is a survey research type with the aim of } \\
\text { analyzing the effect of the Adversity Quotient on the entrepreneurial } \\
\text { motivation of students in the economics faculty of the State University of } \\
\text { Padang. The total population is } 1,209 \text { students. Samples were taken } \\
\text { using proportional random sampling technique with a sample of } 300 \\
\text { students. In collecting data, a questionnaire was used as the technique of } \\
\text { collecting it. Simple regression analysis is a data analysis technique used } \\
\text { with the help of the SPSS } 16 \text { program. Based on the data analysis, the } \\
\text { results are sig }<0.00 \text { with } t \text { hit }>\mathrm{t} \text { tab }(15.325>2.59) \text { so it can be } \\
\text { concluded that the adversity quotient has a positive and significant effect } \\
\text { in increasing motivation. student entrepreneurship. }\end{array}$ \\
\hline 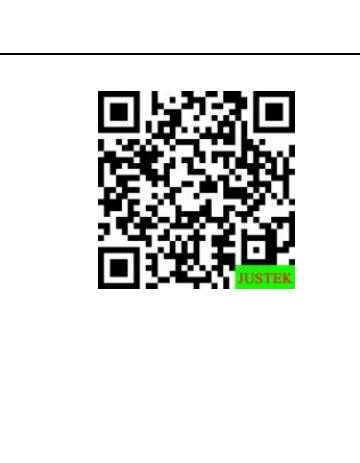 & $\begin{array}{l}\text { Abstrak: Penelitian ini berjenis penelitian survey dengan tujuan untuk } \\
\text { menganalisis efek Adversity Quotient terhadap motivasi berwirausaha } \\
\text { mahasiswa di fakultas ekonomi Universitas Negeri Padang. Jumlah } \\
\text { populasi adalah } 1.209 \text { orang mahasiswa. Sampel diambil dengan } \\
\text { menggunakan teknik proportional random sampling dengan sampel } \\
\text { berjumlah } 300 \text { orang mahasiswa. Dalam pengumpulan data digunakan } \\
\text { angket sebagai teknik pengumpulannya. Analisis regresi sederhana } \\
\text { merupakan teknik analisis data yang dipakai dengan bantuan program } \\
\text { SPSS 16. Berdasarkan analisis data didapatkan hasil sig }<0.00 \text { dengan } t \\
\text { hit }>\text { tab tab.325 }>2.59 \text { ), sehingga diperoleh kesimpulan bahwa adversity } \\
\text { quotient memiliki pengaruh yang positif dan signifikan dalam } \\
\text { meningkatkan motivasi berwirausaha mahasiswa. }\end{array}$ \\
\hline
\end{tabular}

do

Crossref

https://doi.org/10.31764/justek.vXiY.ZZZ This is an open access article under the CC-BY-SA license

\section{A. LATAR BELAKANG}

Kewirausahaan berarti sebuah usaha untuk mencapai proses yang dinamis demi menggapai kemakmuran dalam masyarakat, Sihombing, A \& Buaton dalam (Fatimah, 2020). Sedangkan kewirausahaan adalah sikap mental dan jiwa yang selalu aktif atau kreatif berdaya, bercipta, berkarya, dan berusaha dalam rangka meningkatkan pendapatan dan nilai tambah dalam kegiatan usahanya(Mardia, Abdurrozzak Hasibuan, Janner Simarmata, 2021).

Mahasiswa yang memiliki jiwa kewirausahaan mempunyai kemampuan untuk berprestasi .Ia mempunyai motivasi yang besar untuk maju dan berkarya. Seorang wirausahawan dapat menyelesaikan permasalahan hidup sendiri dan tidak mengharapkan bantuan dari pihak lain. Berdasarkan hasil observasi awal yang dilakukan, motivasi mahasiswa FE UNP untuk berwirausaha masih tergolong 
rendah.Rendahnya motivasi berwirausaha mahasiswa tersebut ditandai dengan sedikitnya mahasiswa FE UNP yang berpartisipasi dalam mengusulkan proposal PKM, khususnya PKM Kewirausahaan. Tinggi rendahnya motivasi peserta terhadap suatu kegiatan akan menentukan tingkat peran sertanya terhadap kegiatan tersebut, dengan demikian apabila seseorang memiliki motivasi yang kuat atau tertinggi terhadap suatu kegiatan maka akan tampak peran sertanya dalam kegiatan tersebut dan sebaliknya, Hasiah dalam (Andriani, 2013).

Faktor yang mempengaruhimotivasi berwirausaha mahasiswa salah satunya adalahadversity quotient. Adversity quotient adalah kesanggupan yang dimiliki seseorang dalam merespon hambatan yang dihadapi guna melaksanakan tugasnya sehingga mampu bertahan dalam menghadapi hambatan serta dapat mengubahnya menjadi peluang meraih keberhasilan, (Firdaus et al., 2019). Adversity quotient memiliki kaitan yang erat dengan dengan motivasi berwirausaha. Mahasiswa yang memiliki adversity quotient yang tinggi akan diikuti oleh motivasi berwirausaha yang tinggi pula dan mahasiswa yang memiliki adversity quotient yang rendah akan memiliki motivasi berwirausaha yang rendah pula. Seperti penelitian yang dilakukan oleh (Sudarman, 2012), dimana hasil penelitiannya menunjukkan bahwa adversity quotient sangat berperan dalam memotivasi siswa belajar matematika. Adversity quotient adalah suatu ukuran untuk mengetahui respons seseorang terhadap kesulitan.

\section{Motivasi Berwirausaha}

Menurut (Razak, 2015), motivasi berwirausaha akan memunculkan tingkah laku untuk berbuat sesuatu dalam rangka mencapai tujuan yang diharapkan. Pada dasarnya motivasi ini terjadi karena adanya keinginan untuk memenuhi faktor-faktor yang belum terpenuhi. Dalam kaitannya dengan wirausaha, keinginan yang belum terpenuhi tersebut adalah ingin bebas mengatur waktu sendiri, ingin memperoleh penghasilan lebih, serta keinginan member kepada orang lain melalui penciptaan lapangan kerja. Motivasi adalah salah satu fasilitas atau kecendrungan individu untuk mencapai tujuan. Individu yang memiliki motivasi akan memiliki kegigihan dan semangat dalam melakukan aktivitasnya. Mereka akan selalu mencoba, meskipun sudah berkali-kali start-up wirausaha yang mereka lakukan gagal. Seseorang dikatakan memiliki motivasi berwirausaha, apabila individu memiliki adanya suatu tujuan yang diharapkan dalam kegiatan bisnisnya, selain itu adanya sikap ulet, gigih, tidak putus asa dalam menyelesaikan tugas bisnis dan memecahkan masalah.

\section{Adversity Quotient}

Menurut Parvathi \& Prasseda dalam (Azaria \& Suprihatin, 2017), kemampuan manusia untuk mengatasi kesulitan dalam hidup disebut dengan adversity quotient. Perjalanan manusia dalam mengarungi kehidupan dan karir diibaratkan seperti mendaki gunung yang menjulan tinggi (Stoltz, 2004). Stoltz mengelompokkan manusia ke dalam tiga golongan dilihat dari cara mendaki, yakni quitters (yang telah menyerah), campers (si pembuat kemah), dan climbers (si pendaki). Quittersialah orang yang mudah menyerah kalau ditantang kesulitan, menghindari tanggung jawab, gampang mundur, dan berhenti. Baginya bekerja hanya untuk mencukupi kebutuhan fisiologisnya. Campers, orang yang mudah puas dengan pencapaiannya.Ia berada dalam area nyaman 
(comfort zone), memutuskan berhenti lalu membuat kemah sebelum mencapai puncak. Climbers, orang yang melihat puncak gunung sebagai tujuannya. Ia tak mudah menyerah serta selalu punya dorongan dan motivasi yang tak ada habis-habisnya sampai ke puncak. Menurut (Sutomo, 2007), konsep ini sangat relevan bagi wirausahawan. Seorang wirausahawan harus memiliki adversity quotient setingkat climbers jika ingin sukses. Tujuan penelitian ini adalah untuk menganalisis efek Adversity Quotient terhadap motivasi berwirausaha mahasiswa di fakultas ekonomi Universitas Negeri Padang.

\section{B. METODE PENELITIAN}

Penelitian ini termasuk penenilitan survey. Penelitian survey adalah penelitian yang dilakukan pada populasi besar maupun kecil, tetapi data yang dipelajari adalah data dari sampel yang diambil dari populasi tersebut, sehingga ditemukan kejadian-kejadian relatif, distribusi, dan hubungan antar variabel sosiologis maupun psikologis (Karlinger dalam (Riduwan, 2010). Penelitian dilakukan di Fakultas Ekonomi Universitas Negeri Padang pada bulan Desember 2015-Maret 2016. Dalam penelitian ini populasi penelitian adalah seluruh mahasiswa Fakultas Ekonomi UNP jenjang S1 dan D3 tahun masuk 20132014 sebanyak 1.029 orang. Jadi jumlah atau ukuran sampel adalah sebanyak 300 orang dengan presisi sebesar 5\%. Sampel ditarik secara proporsional random sampling. Data dianalisis menggunakan analisis regresi sederhana dimana sebelum dilakukan pengumpulan data instrumen telah diuji validitas dan reliabilitasnya. Selanjutnya dilakukan pengujian inferensial dan Uji t untuk menguji pengaruh variabel adversity quotient terhadap motivasi berwirausaha.

\section{HASIL DAN PEMBAHASAN}

Instrumen yang sebelumnya telah diuji validitas dan reliabilitasnya kemudian disebarkan ke responden untuk selanjutnya dideskripsikan berdasarkan keadaan sebenarnya. Setelah lulus uji inferensial berupa homigenitas dan normalitas dilakukan pengolahan data untuk uji hipotesis dan analisis regresi. Berdasarkan hasil pengolahan data, maka diperoleh hasil sebagai berikut:

Tabel 1. Analisis RegresiSederhana

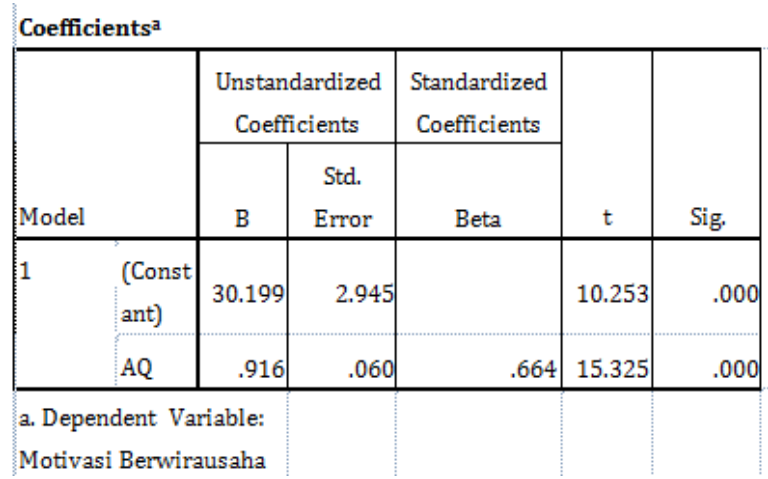

Berdasarkan tabel 1 diperoleh persamaan regresi sebagai berikut:

$\mathrm{Y}=\mathrm{a}+\mathrm{bX}$

$\mathrm{Y}=30.199+0.916 \mathrm{X}$ 
Berdasarkan persamaan tersebut diketahui adanya hubungan yang positif antara adversity quotient terhadap motivasi berwirausaha. Begitu pula dengan uji hipotesis berdasarkan table 1 menunjukkan bahwa $\mathrm{H}_{0}$ ditolak dengan demikian dinyatakan bahwa adversity quotient berpengaruh positif dan signifikan terhadap motivasi berwirausaha.

Hal ini berarti bahwa semakin tinggi adversity quotient mahasiswa maka akan semakin tinggi pula motivasinya untuk berwirausaha. Semakin tinggi adversity quotient maka akan semakin tinggi pula motivasi mahasiswa untuk berwirausaha. Penelitian ini membuktikan bahwa kecerdasan mahasiswa dalam mengatasi kesulitan dan menghadapi tantangan mempengaruhi motivasinya untuk berwirausaha atau tidak. Semakin tinggi kecerdasan yang dimiliki seorang mahasiswa dalam mengatasi kesulitan dan menghadapi tantangan maka mahasiswa tersebut akan semakin terdorong dan termotivasi untuk berwirausaha.Tinggi rendahnya adversity quotientakan dipengaruhi oleh faktor CO2RE. Sehingga dengan prinsip CO2RE (Control (Kendali), Origin dan Ownership (Asal usul dan pengakuan), Reach (jangkauan), Endurance (daya tahan), sebagai entrepeneur kita akan lebih terampil mengelola mental untuk mencapai puncak, (Sutomo, 2007).

Mahasiswa yang memiliki kendali yang tinggi terhadap kesulitan atau peristiwa yang dialaminya tidak akan mudah menyerah dan mencari penyelesaian dari masalah yang terjadi. Adanya kendali yang tinggi atas suatu permasalahan yang terjadi akan mempengaruhi dimensi-dimensi yang lain. Mahasiswa dengan kendali yang tinggi akan cenderung mengakui akibat yang timbul dengan penuh rasa tanggungjawab untuk menyelesaikan permasalahan yang dihadapinya dengan berorientasi pada tindakan. Mahasiswa dengan kendali atau kontrol yang tinggi akan mampu untuk melokalisir suatu tantangan pada tempatnya, tidak meluas, dan menjalar ke mana-mana. Selanjutnya, kendali yang tinggi oleh mahasiswa juga akan menambah daya tahannya terhadap kesulitan. Mahasiswa dengan daya tahan yang tinggi tidak akan menganggap suatu masalah sebagai sesuatu yang sulit dan berlarut-larut.

Kendali yang tinggi pada akhirnya akan mempengaruhi dimensi-dimensi yang lain sehingga mampu menciptakan kecerdasan mahasiswa yang tinggi pula dalam menghadapi tantangan sehingga akan menumbuhkan motivasi untuk berwirausaha, baik itu motivasi yang terjadi atas dorongan kebutuhan fisik, kebutuhan rasa aman, kebutuhan sosial, kebutuhan pengakuan, maupun kebutuhan aktualisasi diri. Tinggi rendahnya adversity quotientakan dipengaruhi oleh dimensi-dimensi di atas. Sehingga dengan dimensi adversity quotient tersebut, sebagai entrepeneur seseorang akan lebih terampil mengelola mental untuk mencapai puncak, Sutomo (2007:73).

Hasil penelitian ini sejalan dengan penelitian yang telah dilakukan oleh (Utami \& Dewanto, 2013). Hasil penelitiannya menunjukkan bahwa adversity quotient mempengaruhi motivasi kerja karyawan. Hal yang sama juga ditemukan oleh (Wisesa \& Indrawati, 2016) yang menenmukan bahwa terdapat hubungan yang positif antara variabel adversity quotient dan variabel motivasi berwirausaha. (Melani, 2017) menyimpulkan hal yang sama berdasarkan penelitiannya bahwa adveristy quotient mempunyai hubungan positif yang signifikan dengan motivasi berwirausaha online 
pada mahasiswa psikologi Universitas Medan Area. Menurut (Riyanti \& Aini, 2018), kecerdasan adversitas memiliki hubungan yang positif dan siginikan dengan motivasi berwirausaha lulusan pendidikan kecakapan hidup keterampilan tata busana di SKB Kabupaten Lima Puluh Kota. Hasil penelitian ini juga sejalan dengan penelitian yang dilakukan oleh (Nelda, 2019) yang menunjukkan adanya hubungan positif antara adversity quotient dengan motivasi berwirausaha pada mahasiswa UIN SUSKA Riau.

\section{SIMPULAN DAN SARAN}

Berdasarkan hasil penelitian dan pengolahan data didapatkan hasil sig<0.00 dengan $t$ hit $>t$ tab (15.325>2.59) yang berarti H0 ditolak dengan demikian disimpulkan dari penelitian ini adalah bahwa adversity quotient memiliki pengaruh yang positif dan signifikan terhadap motivasi berwirausaha mahasiswa FE UNP. Beberapa hal yang dapat disarankan berdasarkan hasil penelitian ini antara lain adalah meningkatkan kecerdasan menghadapi tantangan dan mengatasi kesulitan dengan melakukan tugastugas yang sulitt, meninjau tingkat adversity quotient mahasiswa, memicu motivasi berwirausaha mahasiswa melalui penawaran hibah atau dana wirausaha, dan lain-lain.

\section{REFERENSI}

Andriani, A. (2013). Hubungan Antara Motivasi Orang Tua Dalam Mendidik Anak Melalui Paud Dengan Partisipasinya Di Paud Kasih Ibu. Spektrum: Jurnal Pendidikan Luar Sekolah (PLS), 1(1), 161. https://doi.org/10.24036/spektrumpls.v1i1.1490

Azaria, U. N., \& Suprihatin, T. (2017). Adversity Quotient Pada Siswa Homeschooling. Proyeksi, 12(2), 79-85.

Fatimah, N. A. S. \& E. S. R. (2020). Pengaruh E-Commerce dan Pengetahuan Kewirausahaan terhadap Minat Berwirausaha pada Pedagang Online di Kota Makassar dalam Perspektif Islam. EL-IQTISQHOD Jurnal Kajian Ekonomi Syariah, 21(1), 1-9.

Firdaus, Y., Sumardi, S., \& Istiadi, Y. (2019). Efektivitas Pengajaran Guru Ditinjau Dari Adversity Quotient Dan Integritas. Jurnal Manajemen Pendidikan, 7(1), 700-706. https://doi.org/10.33751/jmp.v7i1.954

Mardia, Abdurrozzak Hasibuan, Janner Simarmata, K. E. L. (2021). Kewirausahaan. Yayasan Kita Menulis.

Melani, I. (2017). Hubungan antara Adversity Quotient dengan Motivasi Berwirausaha Online pada Mahasiswa Psikologo Universitas Medan Area.

Nelda, D. T. (2019). Hubungan Adversity Qoutient dengan Motivasi Berwirausaha pada Mahasiswa UIN SUSKA RIAU.

Razak, A. \& M. (2015). Kewirusahaan, Teori dan Aplikasi, Strategi Membangun Kerajaan Bisnis. MAGNAscript Publishing.

Riduwan. (2010). Metode dan Teknik Menyusun Tesis. Alfabeta.

Riyanti, Y., \& Aini, W. (2018). Hubungan Kecerdasan Adversitas dengan Motivasi Berwirausaha Lulusan Pendidikan Kecakapan Hidup Keterampilan Tata Busana di SKB Kabupaten Lima Puluh Kota. Spektrum: Jurnal Pendidikan Luar Sekolah (PLS), 1(4), 498. https://doi.org/10.24036/spektrumpls.v1i4.101631

Stoltz, P. G. (2004). Adversity Quotient Mengubah Hambatan Menjadi Peluang. PT. Grasindo.

Sudarman. (2012). Adversity Quotient Pembangkit motivasi siswa dalam belajar matematika. Ilmiah Pendidikan, 11(2), 36-40. 
Sutomo, D. (2007). Entrepeneur Jempolan (Achieving Entrepreneurial Excellence). Republika.

Utami, E. W., \& Dewanto, A. (2013). Pengaruh adversity quotient terhadap kinerja perawat dengan motivasi kerja sebagai variabel mediasi (Studi di RSUD "Ngudi Waluyo" Wlingi). Jurnal Aplikasi Manajemen, 11(1), 1-11.

Wisesa, D., \& Indrawati, K. R. (2016). Hubungan Adversity Quotient Dengan Motivasi Berwirausaha Pada Mahasiswa Universitas Udayana Yang Mengikuti Program Mahasiswa Wirausaha. Jurnal Psikologi Udayana, 3(2), 187-195. https://doi.org/10.24843/jpu.2016.v03.i02.p02 